\title{
MANAJEMEN SURAT MASUK DAN SURAT KELUAR DI UNIVERSITAS NEGERI SEMARANG MELALUI SIRADI (SISTEM INFORMASI SURAT DINAS)
}

\author{
Agung Kuswantoro'1), Ratu Bunga Maremitha Ungu²), Wanda Dwi Rahmahwati³), Fentya Dyah \\ Rahmawati ${ }^{4}$ ) \\ 1,2,3,4) Fakultas Ekonomi, Universitas Negeri Semarang, Semarang, Indonesia \\ 1) agungbinmadik@mail.unnes.ac.id, 2) maremitha@gmail.com, 3)wandadwi1997@gmail.com, 4) \\ fentyadyah@gmail.com
}

\begin{abstract}
ABSTRAK penelitian ini adalah penelitian kualitatif deskriptif. Teknik pengumpulan data yang digunakan yaitu metode kepustakaan dan studi lapangan. Kesimpulan penelitian yaitu (1) Manajemen surat masuk dan keluar dikelola Manajemen Surat secara elektronik menggunakan SIRADI, (2) Pada pengelolaan surat masuk, SIRADI BUHK UNNES, (3) Pada tahap pencatatan surat masuk, terdapat unit kerja yang membutuhkan buku agenda. Surat masuk yang berbentuk fisik discan terlebih dahulu dan fisik surat akan disimpan oleh pihak yang tertuju dalam surat masuk, (4) Pada tahan penyiapan konsep surat keluar dilakukan secara manual (fisik), surat diproses melalui SIRADI. Surat keluar berwujud fisik dikirim menggunakan buku ekspedisi, (5) Terdapat kendala factor jaringan dan Sumber Daya Manusia (SDM) yaitu masih ada unit kerja yang tidak melakukan digitalisasi pada surat yaitu meng-scan dan mengupload file surat serta kesalahan input dalam memberikan kode klasifikasi/nomor surat. Saran yang dapat peneliti rekomendasikan dalam penelitian ini antara lain: (1) Perlu peningkatan kualitas jaringan internet, sehingga memperlancar proses manajemen surat masuk dan surat keluar melalui SIRADI, (2) Perlu adanya kesatuan pemahaman antara staf pada setiap unit kerja dengan diadakannya sosialisasi alur persuratan oleh pihak kampus, sehingga dalam manajemen surat masuk dan keluar tidak ada tahap terlewati, (3) Menulis pada buku agenda atau ekspedisi surat masuk, sehingga ketika dibutuhkan dapat melihat pada buku guna mengurangi kesalhan input.
\end{abstract}

ARTIKEL INFO

Penelitian ini bertujuan (1) Mengetahui sistem manajemen surat masuk dan Diterima: 10 September 2021 keluar di UNNES melalui SIRADI, (2) Mengetahui kendala dalam melakukan Direvisi: 09 Oktober 2021 manajemen surat masuk dan surat keluar di UNNES melalui SIRADI. Jenis Disetujui: 25 Oktober 2021 surat diterima secara terpusat pada Sub Bagian Tata Usaha, Bagian Umum Surat Masuk dan Keluar

\section{ABSTRACT}

\section{KEYWORDS}

The purpose of the study are (1) To know the management of incoming and Management Mail outgoing mail at UNNES through SIRADI, (2) To know the obstacles faced in the SIRADI management of incoming and outgoing mail at UNNES through SIRADI. The Incoming and Outgoing Mail type of research used is descriptive qualitative research. Data collection techniques are literature research methods and field study methods. The conclusion in this study is (1) The management of incoming and outgoing mail has been managed electronically using SIRADI, (2) On the management of incoming mail, the letter is received centrally in the General Section of BUHK UNNES, (3) At the entry letter recording stage, there is still a work unit that requires an agenda book to record incoming mail, (4) At the stage of preparation of the concept of exit letter is done manually then the letter will be Jurnal Pustaka Budaya https://journal.unilak.ac.id/index/php/pb 
processed through SIRADI, (5) There are constraints such as network and human resources factor, there are still work units that do not digitize the letter i.e. by scanning and uploading mail files. Suggestions of this study are: (1) Need to improve the quality of the internet network to reduce network disturbances, thereby expediting the process of managing incoming and outgoing mail through SIRADI, (2) Need to have a unity of understanding between the staff at each work unit, (3) Writing in an agenda book or expedition book, so that when needed can look at the book to reduce input error.

\section{Pendahuluan}

Komunikasi adalah aspek yang penting dan sangat dibutuhkan dalam sebuah instansi atau organisasi. Komunikasi merupakan salah satu indikatoruntuk menciptakan dan memelihara sistem pengukuran kinerja yang baik (Sedarmayanti, 2008: 200). Organisasi maupu tatanan kerja yang memiliki komunikasi yang buruk maka dapat diindikasikan hasil kerja juga tidak maksimal. Hal ini sejalan dengan Mulyono (2008: 31) bahwa komunikasi merupakan penafsiran pesan dari beberapa unit dalam sebuah organisasi. Adanya komunikasi yang baik maka distribusi informasi dapat berjalan dengan optimal.

Berbagai macam alat komunikasi digunakan dalam pendistribusian informasi pada suatu organisasi atau instansi, salah satunya adalah surat. Surat merupakanalat komunikasi dalam bentuk tertulis dari komunikator (pengirim informasi) kepada komunikan (penerima informasi) untuk menyampaikan suatu informasi atau tujuan tertentu(Asriel dkk, 2016: 104). Hal ini didukung oleh penelitian Sitohang (2018: 7) yang menjelaskan bahwa surat merupakan alat komunikasi tertulis dengan tujuan menyampaikan informasi dan pesan dari satu pihak kepada pihak lainnya, baik dalam lingkup organisasi dengan organisasi, individu dengan individu atau individu dengan kelompok.Tidak hanya sebagai alat komunikasi, namun fungsi surat juga sangat beragam, seperti: bukti autentik organisasi, duta organisasi, barometer organisasi, serta dasar pengambilan keputusan atau kebijakan.

Surat efektif sebagai alat komunikasi formal suatu organisasi. Hal ini didukung oleh Masykur dan Atmaja (2015: 2) bahwa surat menjadi alat komunikasi yang efektif untuk bertukar informasi dan menjadi bukti autentik dalam kondisi tertentu. Berbeda dengan sarana atau media komunikasi lainnya, berbagai manfaat dimiliki surat untuk organisasi. Suryani, dkk (2014:2) menjelaskan bahwa fungsi surat meliputi alat bukti autentik dalam bentuk tertulis, bukti historis atau sejarah, duta organisasi, barometer organisasi, alat pengingat dan sebagai pedoman dalam pengambilan keputusan maupun kebijakan.
Era digitalisasi sangat erat kaitannya dengan teknologi. Banyak berkembang teknologi yang canggih sebagai bentuk upaya efisiensi dan efektivitas penyampaian informasi dalam organisasi. Hal ini harapannya dapat membantu dalam menunjang berjalannya kegiatan administrasi pada lingkup organisasi ataupun instansi pemerintah maupun swasta.

Kemajuan teknologi yang pesat ini tidak lantas menghilangkan peran surat dalam sebuah organisasi atau instansi, melainkan teknologi ini sebagai pendamping dalam ketercapaian efisiensi dan efektivitas pendistribusian informasi dalam surat yang dikemas dengan teknologi.

Penelitian yang dilakukan oleh Badea (2014:74), mengatakan bahwa dengan adanya teknologi melalui sosial media mampu meningkatkan komunikasi organisasi. Hal ini sejalan dengan Prasanti (2017: 71) yang menyatakan perkembangan berbagai bentuk teknologi, tertutama teknologi informasi sangat berpengaruh terhadap perkembangan komunikasi sehingga menyebabkan komunikasi dengan segera (instantaneous), instan dan virtual, maka interaksi atau face to face communication kini diambil alih oleh komunikasi yang dilakukan melalui platform-platform digital. Hal ini berlaku juga pada komunikasi melalui surat-menyurat, yang awalnya manual, namun kini berkembang dengan adanya surat elektronik dan berbagai sistem yang lain.

Pengelolaan persuratan dalam organisasi sangat penting untuk dikaji mendalam, mengingat masih terdapat organisasi yang belum memiliki pengelolaan surat yang tersistem rapih. Kulcu (2009: 459) menyatakan bahwa proses kelembagaan di perguruan tinggi yang berkaitan dengan dokumen atau persuratan belum mampu memenuhi persyaratan hukum dan administrasi karena dalam penerapannya terdapat dokumen yang keliru, kurangnya struktur administrasi yang berkualitas, sistem manajemen dokumen yang kurang efektif dan karyawan yang kurang kompeten. Hal ini didukung oleh penelitian Utomo dan Daryoto (2018: 10) bahwa manajemen surat yang efektif perlu adanya prosedur manajemen surat yang jelas dan penyimpanan surat yang aman. Selanjutnya, Setyawati (2018: 138) 
menyatakan bahwa untuk menunjang pendistribusian informasi yang memadai, diperlukan sarana prasarana, prosedur manajemen dokumen dan filling yang tersistem.

Sebelum era teknologi, banyak permasalahan yang muncul dalam pengelolaan surat karena masih dilakukan secar manual. Permasalahan manajemen surat secar manual tersebut antara lain: pendistribusian surat yang kurang efektif dan efisien, tercecernya surat hingga terdapat surat maupun informasi yang hilang karena beberapa factor baik human error maupun manajemen surat yang kurang tertib. Sedangkan pada era teknologi informasi ini, salah satu bentuk layanan yang dapat digunakan yaitu internet (Ivancevich, dkk, 2006:124). Layanan internet ini mencakup surat elektronik (e-mail), berita, dan chat room. Jejak digital dari informasi-informasi yang dibagikan melalui aplikasi maupun platform komunikasi ini lebih mudah untuk didokumentasikan dalam bentuk elektronik.

Madanchian dan Hamed (2015:1082) dalam penelitiannya mengatakan bahwa sebagian besar karyawan organisasi telah menggunakan e-mail sebagai alat komunikasi dan melakukan tugas sehari-hari yang berhubungan dengan pekerjaan kantor melalui e-mail.Hal ini didukung oleh Hasanah dkk (2018: 155) bahwa media yang paling efektif untuk menyampaikan informasi dalam organisasi adalah e-mail atausurat elektronik. Jika ditinjau dari manfaatnya, e-mail sangat memudahkan organisasi dalam pendistribusian informasi secara formal.

Kemudahan organisasi berkomunikasi melalui e-mail tidak hanya sebatas bertukar informasi, namun informasi yang dikirim melalui email dapat dijadikan sebagai bukti autentik pada kondisi tertentu, sama hal nya dengan surat menyurat yang dilakukan secara manual. Hal ini didukung oleh penelitian Heniyatun dkk (2018: 30) bahwa informasi elektronik termasuk informasi melalui e-mail dapat pembuktian atau bahan bukti penyelesaian perkara di pengadilan. Hal ini mengindikasikan bahwa transformasi surat manual menjadi digital tidak menghilangkan fungsi surat tersebut.

Digitalisasi dan globalisasi menuntut setiap organisasi atau instansi mampu mengikuti perkembangan teknologi, salah satunya adalah penggunaan persuratan berbasis elektronik. Selain paperless, surat elektronik juga lebih efektif, singkat dalam proses, dan pendokumentasikan atau pengarsipan yang lebih mudah. Selain itu, perkembangan sistem informasi e-government menjadi salah satu acuan dalam pengaplikasian teknologi persuratan pada organisasi atau instansi. Hal ini didasari dari Instruksi Presiden Republik Indonesia tahun 2003 mengenai pengembangan e-government yang transparan dan demokratis. Selanjutnya, penelitian Prasetyo dan Kurniawan (2016: 5) menguatkan bahwa dengan menggunakan komputer atau teknologi menjadikan pengelolaan surat masuk dan keluar menjadi lebih efektif, sedangkan dokumen yang dihasilkan juga dapat diarsipkan secara elektronik.

Penggunaan persuratan berbasis elektronik sudah digalakkan pada Universitas Negeri Semarang (UNNES). Penerapan penggunaan aplikasi berbasis elektronik ini, sebagai wujud pengimplementasian pemerintahan berbasis Good Governance. Penerapan persuratan berbasis elektronik ini diharapkan dapat memenuhi kebutuhan dari internal universitas, mahasiswa, masyarakat maupun stakeholder yang terlibat, terutama penyediaan kebutuhan informasi.

Hal ini sejalan dengan prestasi UNNES dimana pernah menjadi Lembaga Kearsipan Perguruan Tinggi (LKPT) harapan ketiga Nasional selama dua periode (tahun 2016 dan 2017). Manfaat penggunaan aplikasi SIRADI ini menurut Bapak Purwanto dalam wawancara tanggal 28 Januari 2020 mengatakan

"SIRADI merupakan sistem persuratan di UNNES yang sudah memiliki standar dalam kaidah korespondensi bahasa Indonesia. Bahkan, sudah dikonsultasikan ke ANRI terkait pola klasifikasi kearsipannya, sehingga dalam SIRADI mengandung unsur tata persuratan dan kearsipan. Semua unit kerja di UNNES menggunakan SIRADI dalam pengelolaan persuratannya karena selain mempermudah dalam pengelolaan surat, juga dapat meminimalisir penggunaan kertas." (Sumber: hasil wawancara tanggal 28 Januari 2020). 


\section{Gambar 1 Kerangka Berpikir}

\begin{tabular}{|c|c|}
\hline \multicolumn{2}{|c|}{$\begin{array}{l}\text { Efektifitas dan efisiensi pengelolaan persuratan } \\
\text { di lingkungan UNNNES }\end{array}$} \\
\hline \multicolumn{2}{|c|}{ Sistem Informasi Surat Dinas/SIRADI } \\
\hline \multicolumn{2}{|r|}{$\downarrow$} \\
\hline $\begin{array}{l}\text { Pengelolaan Surat Masuk: } \\
\text { 1. Penerimaan } \\
\text { 2. Pengarahan } \\
\text { 3. Penilaian } \\
\text { 4. Pencatatan } \\
\text { 5. Penyimpanan } \\
\text { 6. Penyampaian } \\
\text { (Nuraida,2014:88) }\end{array}$ & $\begin{array}{l}\text { Pengelolaan Surat Keluar: } \\
\text { 1. Penyiapan Konsep } \\
\text { 2. Pengelompokkan } \\
\text { 3. Pencatatan } \\
\text { 4. Penyampaian / } \\
\text { Pendistribusian } \\
\text { (Nuraida,2014:92) }\end{array}$ \\
\hline & $\downarrow$ \\
\hline \multicolumn{2}{|c|}{ Kendala/Hambatan } \\
\hline \multicolumn{2}{|r|}{$\downarrow$} \\
\hline \multicolumn{2}{|c|}{ Saran dan Masukan } \\
\hline
\end{tabular}

\section{Metode Penelitian}

Jenis penelitian ini yaitu penelitian kualitatif deskriptif. Moleong (2016:6) menjelaskan "penelitian kualitatif merupakan penelitian yang bertujuan untuk memahami fenomena yang terjadi pada subyek penelitian misalnya perilaku, anggapan atau persepsi, motivasi, niat, minat, tindakan, dan sebagainya baik secara holistik maupun deskripsi dalam bentuk kata-kata dan bahasa dengan menggunakan berbagai metode alamiah."

Berdasarkan pendekatan penelitian yang digunakan maka data yang didapatkan dalam penelitian menghasilkan bentuk data deskriptif berupa kata-kata. Pada metode penelitian kualitatif ini peneliti mendapatkan informasi, keterangan-keterangan hingga gejala-gejala di lapangan dengan melakukan pengamatan dalam proses penelitian tentang manajemen surat di UNNES.

Penelitian ini berfokus pada manajemen surat masuk dan surat keluar di UNNES melalui SIRADI. Lokasi penelitian dilaksanakan di UNNES dengan pengelola adalah Subbagian Tata Usaha bekerjasama dengan UPT TIK dan UPT Kearsipan.

Sumber penelitian meliputi dari dua sumber yaitu sumber penelitian primer dan sekunder. Sugiyono (2016:225) menjelaskan "sumber primer adalah data-data yang diperoleh secara langsung oleh peneliti, data primer tersebut diperoleh dengan cara merekam atau mencatat melalui wawancara langsung dengan pihak-pihak yang terlibat dalam penelitian." Berikut data primer dari penelitian ini:
Tabel 1

Data Primer

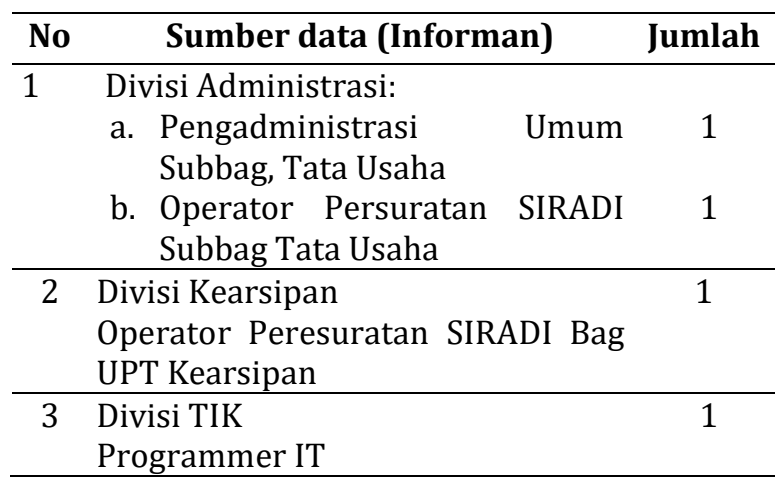

Sumber: Data Penelitian (2020)

Selanjutnya, Sugiyono (2016: 225) menyatakan "sumber sekunder adalah sumber data yang diperoleh peneliti secara tidak langsung." Data sekunder atau pendukung merupakan dokumen resmi dengan data yang bersifat dan berwujud non manusia di UNNES terkait manajemen persuratan.

Data yang dikumpulkan melalui teknik observasi secara langsung, wawancara, dan studi literature atau dokumen. Pelaksanaan observasi dilakukan untuk mengamati secara langsung kegiatan manajemen surat sehigga peneliti dapat memperoleh informasi atau data tentang manajemen surat masuk dan keluar pada UNNES melalui SIRADI.

Selanjutya, wawancara dilakukan bertujuan mendapatkan data lebih mendalam terkait manajemen surat masuk dan surat keluar melalui Siradi pada UNNES. Wawancara pada penelitian ini dilakukan langsung oleh peneliti kepada informan untuk mendapatkan informasi terpercaya dan akurat. Penggunaan teknik wawancara sebagai pengontrol supaya tidak terjadi penyimpangan pada masalah yang diteliti yaitu mengenai Manajemen Surat Masuk dan Surat Keluar di UNNES melalui SIRADI.

Studi literature atau dokumen juga dilakukan dalam penelitian ini. Studi literature atau dokumen yang dilakukan meliputi informasi dan data melalui dokumen baik dokumen tertulis, dokumen elektronik dan gambar yang kesemuanya itu berhubungan dengan fokus penelitian. Studi dokumen merupakan studi yang diarahkan untuk data yang sudah dianggap valid dan tidak diragukan lagi kebenarannya. Dokumen tersebut bertujuan sebagai alat kontrol untuk memastikan keakuratan dari hasil observasi dan wawancara. 
Teknik analisis data melalui dua cara yaitu analisis sebelum dan selama di lapangan. Sugiyono (2016:90) menjelaskan bahwa analisis sebelum di lapangan dimana penelitian kualitatif sudah menganalisis data sebelum peneliti melakukan observasi awal. Melakukan analisis terhadap data sekunder atau data hasil studi pendahuluan sebagai penentu fokus penelitian. Fokus penelitian pada penelitian kualitatif sifatnya sementara dan terus berkembang sesudah peneliti masuk dan melakukan penelitian mendalam di lapangan.

Moleong (2016: 103) menyatakan bahwa analisis data bisa diartikan suatu proses mengatur urutan data, mengorganisasi sesuai dengan uraian dasar dan kategori yang seharusnya. Analisis data sangat penting untuk tercapainya tujuan penelitian. Burhan Bungin (2003:70) menjelaskan bahwa analisis data secara runtut dapat dimulai dengan pengumpulan data, reduksi, display data, verifikasi dan penegasan kesimpulan. Pengumpulan data atau data collection merupakan langkah awal dari kegiatan analisis data, dimana bisa dilakukan dengan observasi, wawancara dan studi literature atau dokumen.

Mereduksi data bermakna suatu proses memilih hal-hal, fokus terhadap hal-hal yang penting, dan melakukan penyederhanaan datadata kasar yang didapat dari lapangan. Hal ini diharapkan bahwa sesudah data direduksi maka data akan memiliki gambaran lebih jelas, dan memudahkan peneliti dalam melengkapi data penelitian secara akurat.

Kemudian, display data yang dilakukan dalam penelitian kuantitatif menyajikan data berbentuk grafik, tabel, dan sejenisnya. Melalui display data tersebut, sehingga data dapat terorganisasikan lebih sistematis bahkan dapat memudahkan peneliti dalam memahami data penelitian yang dibutuhkan. Display data merupakan proses pendeskripsian informasi yang penting agar dapat memberikan kepastian yang tepat untuk menarik kesimpulan dan mengambil tindakan.

Tahap terakhir analisis data penelitian kualitatif adalah verifikasi dan penarikan kesimpulan. Pengumpulan data, reduksi data dan display data merupakan serangkaian proses analisis data yang membentuk adanya verifikasi dan penarikan kesimpulan penelitian. Setiap proses tersebut dilakukan untuk memperoleh data yang absah dengan menelaah data yang diperoleh berdasarkan sumber dari lapangan. Pemeriksanaan yang intens ini dapat meningkatkan dan mengakuratkan efektivitas dan efisiensi dalam penarikan kesimpulan.
Moleong (2016:324) menyatakan bahwa penelitian kualitatif yang baik harus menetapkan derajat keabsahan (trustworthiness) data. Keabsahan data dapat diketahui melalui teknik pemeriksaan. Indikator atau kriteria tertentu diperlukan untuk mengukur keabsahan data penelitian. Kriteria yang digunakan yaitu Derajat Kepercayaan, Keteralihan, Kebergantungan dan Kepastian.

Derajat Kepercayaan (kredibilitas) menggantikan konsep validitas internal dan non kualitatif. Fungsi kriteria ini menjalankan inkuiri yang ketat dan tersistem sehinggatingkat kepercayaan penemuannyadapat tercapai dan memperlihatkan derajat kepercayaan pada hasilhasil penemuan melalui pembuktian oleh peneliti pada objek penelitian.

Keteralihan (transferability) berdasar kesamaan antara konteks pengirim (sumber data atau informan) dan penerima (peneliti). Peneliti mencari dan mengumpulkan kejadian empiris mengenai kesamaan menyampaian informasi penelitian. Sehingga peneliti mempunyai tanggung jawab menyediakan data deskriptif secukupnya apabila akan memutuskan pengalihan tersebut. Peneliti harus menjalankan penelitian kecil supaya memastikan usaha memverifikasi terhadap keperluan tersebut.

Kebergantungan (dependability) yaitu istilah reliabilitas dalam penelitian non kualitatif. Pada kriteria ini, menunjukkan reliabilitas melalui pengadaan replikasi studi. Reliabilitas sangat penting dalam data penelitian, karena tanpa data yang reliable maka kebenaran dan kualitas data penelitian diragukan. Apabila dua atau beberapa kali pengulangan studi terhadap kondisi yang sama dan secara esensial hasilnya juga sama, sehingga reliabilitas dinyatakan tercapai.

Kepastian (confirmability) asalnya dari konsep objektivitas berdasarkan non kualitatif. Non kualitatif menetapkan objektivitas dari segi kesepakatan antar subjek. Memastikan suatu hal yang objektif atau tidak disesuaikan dari persetujuan beberapa orang terhadap pendapat, pandangan dan penemuan. Pengalaman seseorang dinyatakan subjektif, namun apabila ada kesepakatan dari beberapa atau banyak orang, baru dinyatakan objektif. Sehingga, objektivitas-subjektivitasnya suatu hal bergantung pada orang seorang.

\section{Hasil dan Pembahasan}

Sistem SIRADI dalam manajemen persuratan di Universitas Negeri Semarang (UNNES) sangat dibutuhkan untuk meningkatkan efektivitas dan efisiensi pekerjaan. Data-data dalam penelitian ini 
diperoleh melalui wawancara dengan informan, dan kemudian didukung oleh analisis hasil wawancara sesuai dengan prosedur penelitian.

A. Pengelolaan Surat Masuk di UNNES melalui SIRADI

Surat masuk dalam organisasi menjadi hal yang penting karena berisi informasi. Asriel dkk (2016: 107) menyatakan bahwa surat masuk merupakan surat yang diterima dari perorangan atau instansi yang berisi informasi yang berguna untuk sebuah organsiasi. Informasi tersebut dapat berupa informasi yang bersifat penting, rahasia, segera maupun umum, tergantung pada jenis surat masuk yang diterima. Nuraida (2014: 65) menguatkan bahwa surat masuk yaitu surat yang diterima dari pihak luar (eksternal instansi) yang berisi informasi.

Setiap surat yang dikeluarkan maupun diterima oleh instansi atau organisasi berisi informasi yang bermanfaat. Fungsi surat sebagai bukti autentik dan pedoman pengambilan kebijakan juga menguatkan bahwa surat masuk atau keluar merupakan dokumen yang berisi informasi yang harus dikelola dengan baik. Endang dkk (2012: 15) mengemukakan bahwa manajemen atau pengelolaan surat masuk melaluibeberapa tahap atau proses, antara lain: a) penerimaan, b) penyortiran, c) pencatatan, d) pengarahan, e) penyampaian, f) penyimpanan. Sedangkan Yatimah (2013: 124) mengemukakan bahwa tahapan pengelolaan surat masuk meliputi: a) penerimaan, b) penyortiran, c) pencatatan, d) pengarahan, e) penyimpanan. Jadi dapat disimpulkan bahwa proses penanganan surat masuk dimulai dari penerimaan dan berakhir pada penyimpanan atau pengarsipan.

Pengelolaan surat masuk di UNNES meliputi tahap penerimaan surat, pengarahan surat, penilaian surat, pencatatan surat, penyimpaanan surat dan penyampaian surat. Dalam pengelolaan suratnya UNNES sangat maju dengan mengunakan SIRADI atau yang disebut juga Sistem Informasi Surat Dinas. Dimana sangat memudahkan kinerja para pegawai dalam pengelolaan suratnya. Berikut adalah alur pengelolaan surat masuk di UNNES, yaitu:

\section{Gambar 2 \\ Prosedur Surat Masuk UNNES}

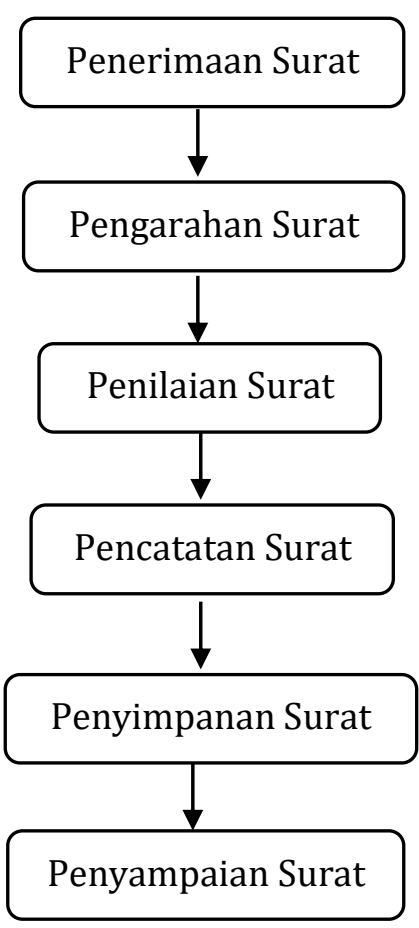

a) Penerimaan Surat Masuk

Dalam tahap ini proses penerimaan surat masuk di UNNES adalah surat diterima terlebih dahulu di bagian tata usaha bagian umum pusat untuk kemudian diproses (tahap input data dan scan) ke dalam SIRADI.

\section{b) Pengarahan Surat Masuk}

Dalam pengarahan surat masuk di lingkungan UNNES adalah surat diterima terlebih dahulu di Bagian Tata Usaha, kemudian surat diinput dan discan melalui SIRADI (kolom surat masuk) untuk disampaikan kepada tujuan surat (pimpinan unit kerja), kemudian fisik asli surat dapat dikirim/ didistribusikan kepada tujuan surat melalui caraka.

c) Penilaian Surat Masuk

Berdasarkan Informasi dari para informan, maka dapat disimpulkan bahwa penilaian surat masuk di UNNES berdasarkan pedoman tata naskah dinas yang meliputi penilaian terhadap kop surat, tanggal, bulan dan tahun surat, tujuan surat, jenis surat, isi surat, tanda tangan dan cap surat.

d) Pencatatan surat masuk

Berdasarkan hasil penelitian pencatatan surat di UNNES pusat sudah menggunakan SIRADI, sedangkan di unit kerja ada yang masih menggunakan buku agenda dalam pencatatan 
surat masuknya untuk mempermudah pencarian surat disaat jaringan internetnya trouble.

e) Penyimpanan surat masuk

Penyimpanan surat masuk di lingkungan UNNES sudah dilakukan secara digitalisasi, atau tersistem melalui SIRADI dan dalam penyimpanan fisik suratnya, surat tersebut disimpan dalam filling cabinet menggunakan map gantung.

f) Penyampaian surat masuk

Penyampaian surat masuk di UNNES untuk unit kerja dapat dilihat langsung melalui SIRADI atau jika ingin menunggu fisik suratnya akan disampaikan oleh caraka.

\section{B. Pengelolaan Surat Keluar}

Pengelolaan surat keluar merupakan rekam jejak organisasi atau instansi terkait, baik dalam menjalin komunikasi, kerjasama maupun hal lain yang penting. Surat keluar dapat dikatakan sebagai surat yang dikirim kepada perseorangan atau instansi, lembaga, organisasi lain (Asriel dkk, 2016: 107).

Wursanto (2004: 249) mengemukakan bahwa proses manajemen surat keluar mencakup: a) pengonsepan surat, b) pengetikan surat, c) pengolahan surat, d) pengiriman surat. Sedangkan, Sedianingsih dkk (2010: 89) menjelaskan bahwa prosedur atau alur manajemen surat keluar yaitu: a) konsep surat, b) pencatatan di buku agenda, c) pengetika surat, d) tanda tangan pimpinan, e) pengecekan surat, dan f) pendistribusian surat.

Pengelolaan surat keluar di Universitas Negeri Semarang (UNNES) menggunakan SIRADI, dimana sistem tersebut sangat membantu kinerja para pegawai.

\section{Gambar 3 \\ Prosedur Surat Keluar UNNES}

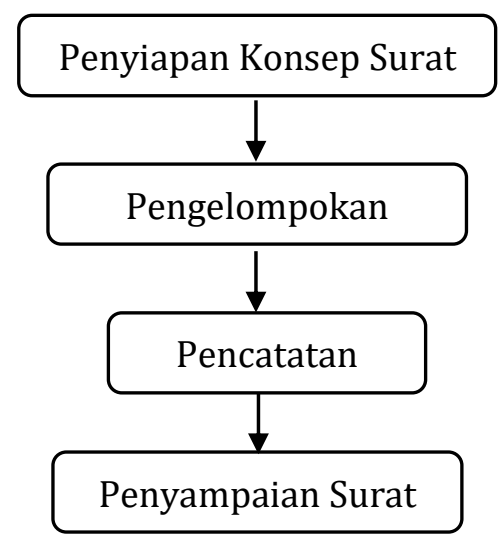

a) Proses Penyiapan Konsep Surat Keluar

Proses penyiapan konsep surat keluar di UNNES dengan membuat draft surat keluar terlebih dahulu dengan memperhatikan hal, jenis kegiatan dan tujuan surat. Kemudian diberikan kepada pimpinan untuk di koreksi terlebih dahulu sebelum dikirim, setelah itu diparaf atau tanda tangan pimpinan.

b) Proses Pengelompokan Surat Keluar

Proses pengelompokan surat keluar dilakukan dengan mengeompokan berdasarkan jenis surat (surat undangan, surat edaran, surat tugas, dll), kelompok surat (surat penting, surat rutin, surat rahasia, surat sangat rahasia, dll), kode surat (KP/ KM/ TU/ KU, dll).

c) Proses Pencatatan Surat Keluar

Proses pencatatan surat keluar di UNNES sudah digital melalui sistem SIRADI. Didalam sistem tersebut terdapat pilihan form input manual surat keluar. Tujuannya yaitu untuk memperoleh nomor agenda. Setelah semua selesai, barulah dimintakan tanda tangan pimpinan untuk selanjutnya dikirim oleh caraka ke tujuan surat tersebut.

d) Proses penyampaian surat keluar

Proses penyampaian surat keluar di UNNES disampaikan melalui sistem SIRADI dan fisik asli surat ditulis terlebih dahulu di dalam buku ekspedisi sebagai bukti, kemudian surat dikirim/ didistribusikan oleh caraka.

\section{Simpulan}

Kesimpulan yang diambil berdasarkan hasil penelitian dan pembahasan tentang manajemen surat masuk dan surat keluar di Universitas Negeri Semarang (UNNES) melalui Sistem Informasi Surat Dinas (SIRADI) antara lain: (1) Manajemen surat masuk dan surat keluar di UNNES dikelola secara elektronik menggunakan Siradi (Sistem Informasi Surat Dinas), (2) Pada pengelolaan surat masuk, surat diterima secara terpusat pada Sub Bagian Tata Usaha, Bagian Umum BUHK UNNES, (3) Pada tahap pencatatan surat masuk, masih terdapat unit kerja yang membutuhkan buku agenda untuk mencatat surat masuk. Surat masuk yang berbentuk fisik akandiscan terlebih dahulu dan fisik surat akan disimpan oleh pihak yang tertuju dalam surat masuk, (4) Pada tahap penyiapan konsep surat keluar dilakukan secara manual (Fisik) kemudian surat akan diproses melalui Siradi. Surat keluar yang berwujud fisik akan dikirim oleh caraka menggunakan buku ekspedisi, (4) Terdapat kendala seperti faktor jaringan dan Sumber Daya Manusia (SDM) yaitu masih ada unit kerja yang tidak melakukan digitalisasi pada surat yaitu dengan meng-scan dan mengupload file surat serta kesalahan input dalam memberikan kode klasifikasi / nomor surat. 
Saran yang dapat diberikan berdasarkan kesimpulan dan penemuan penelitian ini, yaitu: (1) Perlu meningkatkan kualitas jaringan internet untuk mengantisipasi terjadinya gangguan jaringan, sehingga dapat meningkatkan efektivitas dan efisiensi dari proses manajemen surat masuk dan surat keluar melalui Siradi, (2) Perlu adanya kesatuan pemahaman antara staf pada tiap-tiap unit kerja, dengan diadakannya sosialisasi terkait alur persuratan oleh pihak kampus, sehingga tidak ada tahapan yang terlewati dalam manajemen surat masuk dan keluar, (3) Menulis pada buku agenda atau buku ekspedisi surat masuk, sehingga ketika dibutuhkan dapat melihat pada buku guna mengurangi kesalahan input.

\section{Daftar Pustaka}

Asriel, dkk. (2016). Manajemen Kantor. Jakarta: Kencana.

Badea, Marius. (2014). "Social Media and Organizational Communication." Elsevier, Procedia - Social and Behavioral Sciences 149 (2014) 70 - 75. Doi: 10.1016/j.sbspro.2014.08.192.

Endang, Sri, dkk. (2012). Modul Penanganan Surat Masuk dan Keluar (Mail Handling). Jakarta: Erlangga.

Hasanah, U., dkk. (2018). "Efektivitas E-mail Sebagai Media Komunikasi Internal Terhadap Kepuasan Komunikasi Karyawan." Inter Komunika, 3(2), 153-167.

Heniyatun, Iswanto, BT., \& Sulistyaningsih, P. (2018). "Kajian Yuridis Pembuktian dengan Informasi Elektronik Penyelesaian Perkara Perdata di Pengadilan." Varia Justicia, 14 (1), 2579-5198.

Ivancevich, John M., Robert Konopaske, Michael T. Matteson. (2006). Perilaku dan Manajemen Organisasi. Edisi Ketujuh Jilid 2. Terjemahan Penerbit Erlangga. Jakarta: Penerbit Erlangga.

Kulcu, O. (2009). "Evolution of E-records Management Practice in E-government: A Turkish Perspective." The Electronic Library, 27 (6), 999 - 1009.

Madanchian, Mitra dan Hamed Taherdoost. (2016). "Perusing of Organizational Culture Effects on E-Mail Communication." Elsevier, Procedia Technology 22 (2016) 1076 1083. Doi: 10.1016/j.protcy.2016.01.152
Masykur, F., \& Atmaja, I. M. P. (2015). "Sistem Administrasi Pengelolaan Arsip Surat Masuk Dan Surat Keluar Berbasis Web." IJNS-Indonesian Journal on Networking and Security, 4(3).

Moleong, Lexy J. (2016). Metodologi penelitian kualitatif. Bandung: PT Remaja Rosdakarya.

Mulyono. 2008. Manajemen Administrasi \& Organisasi Pendidikan. Yogjakarta: ArRuz Media..

Nuraida, Ida. (2014). Manajemen Administrasi Perkantoran. Yogyakarta: Kanisius.

Prasanti, Dhita. (2017). "Perubahan media komunikasi dalam pola komunikasi keluarga di era digital." Commed: Jurnal Komunikasi dan Media, 1(1), 69-81.

Prasetyo, Erma \& Kurniawan, Amin Taufiq. (2016). Jurnal Ilmu Perpustakaan. Universitas Diponegoro.

Sedarmayanti. (2008). Manajemen Sumber Daya Manusia (Reformasi Birokrasi dab Manajemen Pegawai Negeri Sipil). Bandung : PT Refikatama..

Sedianingsih, dkk. (2010). Teori dan Praktik Administrasi Kesekretarisan. Jakarta: Kencana.

Setyawati, R. K. (2018). "Efisiensi Pengelolaan Dokumen Berupa Surat (Studi Kasus PT Astra Internasional Tbk)." Jurnal Administrasi dan Kesekretarisan, 2 (2), 138 $-149$.

Sitohang, H. T. (2018). "Sistem Informasi Pengagendaan Surat Berbasis Web Pada Pengadilan Tinggi Medan." Journal of Informatic Pelita Nusantara, 3(1).

Sugiyono. (2016). Metode Penelitian Kuantitatif, Kualitatif, dan R\&D. Bandung: Alfabeta.

Suryani, Nanik, Agung Kuswantoro dan Mulyono. (2014). Korespondensi Bahasa Indonesia. Yogyakarata: Graha Ilmu.

Utomo, K. P., \& Daryoto, D. (2018). “Analisis Sistem Pengelolaan Surat Masuk dan Keluar di Pemerintah Kota Bekasi (Studi Kasus pada Bagian Bina Ekonomi, Pembangunan dan Bina Ketahanan Pangan Sekretariat Daerah Kota Bekasi)." Jurnal Administrasi dan Kesekretarisan, 3 (1), 10 - 19.

Wursanto, I.G. (2004). Dasar-dasar IImu Organisasi. Yogyakarta: Andi Offset.

Yatimah, D. (2013). Kesekretarisan Modern dan Administrasi Perkantoran. Bandung: CV Pustaka Setia. 